\title{
INCIDENTAL RELEASE OF BITUMEN DURING OIL SHALE GRINDING AND IMPACTS ON OIL SHALE BENEFICIATION
}

\author{
N. E. ALTUN* \\ Muğla University, Mining Engineering Department \\ 48000, Kötekli, Muğla, Turkey
}

\begin{abstract}
The particle surface characteristics of oil shale and the changes in these characteristics with increasing fineness were determined. FTIR and electrokinetic studies showed that the surfaces of oil shale particle were controlled by oxygen-rich polar groups. FTIR and XPS studies showed that with increasing fineness the polar oxides decreased and organic surface groups increased at grind sizes finer than 100 microns. Flotation was used to view the impact of the changes in surface characteristics on oil shale beneficiation. Formation of an organic surface layer affected separation adversely and selectivity between organic and inorganic entities could not be achieved below 100 microns. Zeta potential values and flotation tests with bitumenextracted oil shale confirmed that bitumen release generates the organic surface coating. The organic layer shifts the native hydrophilicity of oil shale to hydrophobic state. Findings imply that determination of a certain grind size is critical to avoid bitumen release and to maintain selectivity between organic and inorganic constituents during oil shale beneficiation.
\end{abstract}

\section{Introduction}

Energy production is one of the most important issues for the global industry. The energy demands of well-developed countries like USA, Canada, and Germany are expected to increase at a stable level, whereas the demand of developing countries is expected to increase by three times in the mid term [1]. Fossil fuels are still the primary energy source. The oil and natural gas reserves in the world are in a depleting trend. The inevitable dependence of the industrialized world on fossil fuels necessitates exploration of new deposits and evaluation of alternatives like oil shales, oil sands, asphaltites etc.

Among the existing alternatives, oil shales are one of the most promising options with large reserves and being wide spread. Several studies investi-

\footnotetext{
*Corresponding author: e-mail nealtun@mu.edu.tr
} 
gating the thermal and combustion characteristics of oil shales [2-4] and the wide utilization of oil shales in Estonia for almost a century [5] as well as in China prove this claim. Due to several specific characteristics of oil shales, their utilization and treatment involve critical differences than lignite [6]. For instance the carbonate-rich inorganic matter content [7] or highly humic/ fulvic feature of most oil shale deposits necessitates a detailed evaluation and modification of possible utilization methods.

Whether utilization as a solid fuel alternative through physical or physico-chemical methods or as an indirect oil source through retorting, all oil shale beneficiation processes require comminution, i.e. reduction of raw oil shale to a certain particle size [8-12]. For instance, for oil shale retorting in a fluidized bed, the run-off-mine oil shale should be comminuted and pulverized to a certain size, as recently noted by Wang and Zhou [10]. Similar means of comminution have been applied to liberate the organic and inorganic fractions of oil shales for flotation beneficiation of El-Lajjun oil shale from Jordan and Himmetoglu and Beypazari oil shales from Turkey $[11,12]$. Particle size reduction allows the liberation of organic rich constituents and inorganic portions and prepares the oil shale for further separation or other beneficiation processes. Insufficient liberation of organic and inorganic portions decreases the efficiency of separation processes. It has been shown that size reduction is a critical issue for fossil fuels involving kerogen and bitumen as their organic constituents. Incidental release of organic matter, particularly bitumen, would change the surface characteristics of particles after grinding. Sparks et al. [13] reported that the bitumen in oil sands causes the formation of an organic coating around particles during preparation for hot water extraction. It has been found that the smeared bitumen layer is a critical issue for oil sands beneficiation and results in deficiencies during the hot water extraction process [13]. Schramm et al. [14] also stated that bitumen has an important role during water-based conditioning and flotation of oil sands. An optimum beneficiation process relies on the control of the surface characteristics of the ground, fine particles and the bitumen/aqueous interface determines the success of the process [14]. Larsen and Kidena studied the hydrous pyrolysis of Bakken oil shale from USA and observed a sudden release of bitumen with some oil as the sample was heated in water [15]. Diaz et al. studied the interfacial properties of bitumen and its fractions extracted from Spanish oil shales at the air-water interface through Langmuir method [16]. They found that bitumen was likely to form a monolayer film of considerable stability at the interface. It was well established that the organic matter in oil shale was composed of bitumen and kerogen [7, 17], and the interactions between the inorganic matter and kerogen-bitumen fractions of oil shale were studied in details by Razvigorova et al. [17]. As mentioned above, on grounds of the studies regarding the characteristics and the release of bitumen and bitumen films, the bitumen in oil shale may have potential impacts on the surface characteristics of particles, and the physical and surface characteristics of oil 
shale particles may change after size reduction. Although the colloidal changes during size reduction or other processes have been reported well for oil sands, possible impacts of bitumen on preparation of oil shale for beneficiation processes have not been studied.

The objective of this study is to identify the surface characteristics of oil shale particles and possible changes occurring in these characteristics due to grinding and with respect to fineness. The role of particle surface changes in a possible beneficiation process was also studied through flotation tests in which the separation of the inorganic and organic portions was attempted.

\section{Material and methods}

\section{Oil shale sample}

Himmetoğlu oil shale from Bolu, Turkey was used in this study. Geological characteristics of Himmetoğlu oil shale were reported by Sener et al. in detail [18]. Himmetoğlu formation is composed of four zones, consisting of a lower layer of green clay and conglomerate, two overlying zones of lignite and subbituminous coal and a massive oil shale layer at the top. The top layer is actually named Himmetoğlu oil shale [18]. Himmetoğlu oil shale is an extremely rich zone with a calorific value of $>20 \mathrm{MJ} / \mathrm{kg}$ in some parts. Kök et al. found that Himmetoğlu oil shale is capable of producing $32.22 \mathrm{l} / \mathrm{t}$ oil through in-situ combustion retorting [19]. The total reserve of Himmetoğlu formation was estimated as 150 million tonnes, and it was suggested as a promising supply for thermal power production [18]. Proximate and ultimate analyses of raw Himmetoğlu oil shale were done according to ASTM D3172-89 and ASTM D3176-89 standards, respectively. The calorific value of the sample was determined using a Parr Oxygen Bomb Calorimeter. The results are shown in Table 1.

Table 1. Characteristics of Himmetoğlu oil shale (as-received)

\begin{tabular}{|l|c|c|c|}
\hline \multicolumn{1}{|c|}{ Proximate analysis } & Weight, \% & Ultimate analysis & Weight, \% \\
\hline Moisture & 5.4 & $\mathrm{C}$ & 54.3 \\
Volatile matter & 38.4 & $\mathrm{H}$ & 8.8 \\
Fixed carbon & 21.4 & $\mathrm{~N}$ & 1.6 \\
Ash & 34.8 & $\mathrm{O}$ & 32.2 \\
Calorific value $(\mathrm{kcal} / \mathrm{kg})$ & 4312 & $\mathrm{~S}$ (total) & 3.1 \\
\hline
\end{tabular}

\section{Surface and particle characterization by FTIR, XPS and electrokinetic measurements}

Surface and particle characterization of Himmetoğlu oil shale was done by FTIR (Fourier Transform Infrared), XPS (X-Ray Photo Electron Spectroscopy) analysis and electrokinetic (zeta potential) measurements. FTIR analysis was done to characterize the surface of raw oil shale and to view 
possible changes on particle surfaces after grinding to different degrees of fineness. FTIR spectra were obtained using a Perkin Elmer, Spectrum 2000 model spectrometer between 4000 and $400 \mathrm{~cm}^{-1}$ at $2 \mathrm{~cm}^{-1}$ resolution using $\mathrm{KBr}$ pellet technique. The outer layer of oil shale particles was analyzed through XPS to compare the raw and ground oil shale. XPS analysis was carried out with a Fiscon Escalab 200R spectrometer using MgK x-ray source. The peak areas on the spectra were integrated and the elements on the outermost surface layer of the particle were found quantitatively. Deconvolution of the carbon peak also allowed evaluation of the carbon functionalities on the particle surface quantitatively. Electrokinetic measurements were performed to determine the zeta potentials of the particles with respect to fineness. The measurements were done using a Malvern PC 602 Model Zeta Sizer. For the measurements a suspension containing 1\% oil shale were prepared with water. The suspension was then injected to a $U$ shaped disposable cell, which was located into the measurement chamber, and the measurements were automatically performed. All the measurements were performed at the natural $\mathrm{pH}$ of the oil shale-water suspension $(\mathrm{pH}=6.8)$.

\section{Sample preparation and flotation tests}

Himmetoğlu oil shale was comminuted to obtain feeds with different fineness. Representative samples were first crushed using a jaw crusher and then ground in a rod mill to obtain feeds of $100 \%$ passing $<200 \mu \mathrm{m},<150 \mu \mathrm{m}$, $<100 \mu \mathrm{m},<75 \mu \mathrm{m},<50 \mu \mathrm{m},<35 \mu \mathrm{m}$ and $<25$ micron sizes. Particle size distributions of the feeds were determined using a Symtatec, Helos H-1305 Laser Sizer. Particle size distributions are shown in Fig. 1. The $d_{50}$ sizes of feeds with different fineness are presented in Table 2.

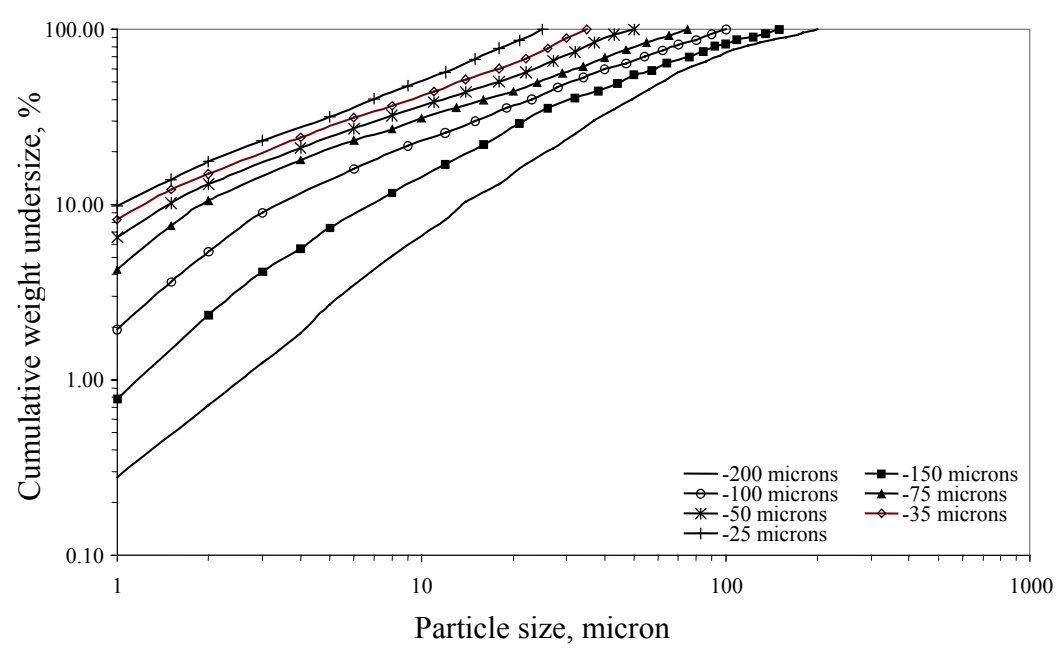

Fig. 1. Particle size distribution of oil shale with respect to grind sizes. 
Table 2. $\mathbf{d}_{\mathbf{5 0}}$ of oil shale feed with respect to fineness

\begin{tabular}{|l|c|c|c|c|c|c|c|}
\hline & \multicolumn{7}{|c|}{$\begin{array}{c}\text { Grind size, } \\
(100 \% \text { passing, microns })\end{array}$} \\
\cline { 2 - 8 } & $<200$ & $<150$ & $<100$ & $<75$ & $<50$ & $<35$ & $<25$ \\
\hline $\mathrm{d}_{50}$ (micron) & 61.6 & 47.5 & 30.9 & 24.3 & 17.8 & 13.3 & 9.7 \\
\hline
\end{tabular}

In order to determine the effect of possible changes of particle size reduction or fineness on oil shale beneficiation flotation method is used. Flotation is a well-known and commonly applied physico-chemical method for enrichment of solid fossil fuels. Previous studies using various collector groups and types showed that the most effective cleaning of Himmetoğlu oil shale, i.e. the separation of inorganic matter, would be achieved through a reverse flotation process using an amine acetate type collector, Flotigam CA. In the reverse flotation process, inorganic constituents of Himmetoğlu oil shale were rendered hydrophobic by the collector (Flotigam CA). The inorganic particles were recovered as the froth product (reject), while the organic-rich, cleaned portion (concentrate) remained in the pulp. Determination of the most favorable flotation method and the conditions for Himmetoğlu oil shale were given elsewhere in detail [20]. The optimum flotation conditions applied are given in Table 3. Single stage batch flotation experiments were carried out with a laboratory type Wedag flotation machine. Flotation tests were repeated at least twice and reproducible results with $\pm 3 \%$ changes were obtained. Flotation products were analyzed for ash content to determine the effectiveness of cleaning. For the ash analysis the concentrate and tailing products were filtered and dried in a laboratory furnace at $75{ }^{\circ} \mathrm{C}$. The dry products were weighed and the ash contents were determined in accordance with the ASTM-D 3174-89 standard.

\section{Table 3. Conditions for flotation tests}

\begin{tabular}{|l|r|}
\hline Particle size & $<100 \mu \mathrm{m}$ \\
Cell volume & $650 \mathrm{ml}$ \\
Pulp density & $10 \%$ solids by wt. \\
Pulp pH & Natural $(6.8)$ \\
Collector type/amount & Flotigam CA (amine acetate) $/ 800 \mathrm{~g} / \mathrm{t}$ \\
Frother type/amount & Aerofroth $65 / 27.5 \mathrm{~g} / \mathrm{t}$ \\
Conditioning time & $15 \mathrm{~min}$ \\
Flotation time & $4.5 \mathrm{~min}$ \\
\hline
\end{tabular}

\section{Extraction of bitumen}

The bitumen in oil shale was extracted and the flotation tests and electrokinetic measurements were repeated with the bitumen-free oil shale. The objective was to determine the amount of bitumen in the sample and to identify possible effects of bitumen on surface characteristics with respect to fineness. Bitumen was extracted using chloroform in a Soxhlet apparatus for 
72 hours. The organic solvent was then evaporated in a rotary evaporator and the extract was made solvent-free. Organic solvent extraction of bitumen, preferably through a Soxhlet apparatus, is the most common and reliable procedure applied for bitumen extraction from oil shales in several previous studies [17, 21-23]. The bitumen amount in Himmetoğlu oil shale was found as $9.78 \%$ by weight.

\section{Results and discussion}

FTIR analysis of the raw oil shale is shown in Fig. 2. The FTIR spectrum shows that the sample is rich in carbon and oxygen containing functional groups. The relatively high intensity of the broad $\mathrm{OH}$ band at $3422 \mathrm{~cm}^{-1}$ points at phenolic hydroxyls and carboxylic $\mathrm{OH}$ groups [24]. The sharp bands at $2926 \mathrm{~cm}^{-1}$ and $2850 \mathrm{~cm}^{-1}$ are due to aliphatic C-H stretching vibrations of $\mathrm{CH}_{3}$ and $\mathrm{CH}_{2}[25,26]$. Additional aliphatic $\mathrm{C}-\mathrm{H}$ peaks were seen at $1452 \mathrm{~cm}^{-1}$ and $1372 \mathrm{~cm}^{-1}$. The peak at $1452 \mathrm{~cm}^{-1}$ is due to the $\mathrm{C}-\mathrm{H}$ bending vibrations of $\mathrm{CH}_{3}$ and $\mathrm{CH}_{2}$ and the peak at $1372 \mathrm{~cm}^{-1}$ is due to $\mathrm{C}-\mathrm{H}$ bending of $\mathrm{CH}_{3}[26,27]$. The band at $1710 \mathrm{~cm}^{-1}$ belongs to the $\mathrm{C}=\mathrm{O}$ stretching vibrations of carboxyl and carbonyl groups $[25,28]$. The broad band at $1625 \mathrm{~cm}^{-1}$ is caused by the $\mathrm{C}=\mathrm{C}$ stretching vibrations of aromatic groups and the $\mathrm{C}=\mathrm{O}$ stretching vibrations of carbonyl groups [24, 29]. The strong $\mathrm{C}-\mathrm{OH}$ band at $1045 \mathrm{~cm}^{-1}, \mathrm{C}-\mathrm{H}$ band at $850 \mathrm{~cm}^{-1}$ and $\mathrm{C}-\mathrm{C}$ band at $675 \mathrm{~cm}^{-1}$ show an intense aromatic matrix in the oil shale $[24,26]$.

Several distinct and strong aliphatic C-H bands (2926, 2850, 1452, $1372 \mathrm{~cm}^{-1}$ ) of $\mathrm{CH}_{3}$ and $\mathrm{CH}_{2}$, the broad aromatic band of $\mathrm{C}=\mathrm{C}$ at $1625 \mathrm{~cm}^{-1}$ and successive aromatic bands of $\mathrm{C}-\mathrm{H}$ and $\mathrm{C}-\mathrm{C}\left(850\right.$ and $\left.675 \mathrm{~cm}^{-1}\right)$ are due to high organic matter content of the sample. Several other strong and broad peaks of hydroxyl, carboxyl and carbonyl groups indicate the humic character of the sample. These oxygen containing functional groups are polar in nature and impose a hydrophilic surface behavior [30,31]. The relatively strong and broad form of the hydroxyl $\left(3422 \mathrm{~cm}^{-1}\right)$ carboxyl and carbonyl bands ( 1710 and $1625 \mathrm{~cm}^{-1}$ ) also reveal the humic character of oil shale.

The FTIR spectra of the raw oil shale and samples ground to $<100,<50$, $<25$ microns are shown in Fig. 2. The comparative spectra show the differences of the particle characteristics with regard to fineness. The FTIR pattern remained identical in general, but the characteristics of the specific peaks changed in intensity and broadness with the grind size (Fig. 2). It should also be noted that the change in the intensity and broadness caused slight variations in the shapes of the peaks at some points, but the peaks still pointed the same groups as their positions remained unchanged, i.e. the peaks occurred at the same wavelengths regardless of fineness (Fig. 2). The intensity of the $\mathrm{OH}$ band of the phenolic hydroxyls, the $\mathrm{C}=\mathrm{O}$ and $\mathrm{C}-\mathrm{OH}$ peaks of carbonyl and carboxyl groups decreased as the oil shale was ground finer. The change in the intensity and the appearance of the $\mathrm{OH}$ band at 


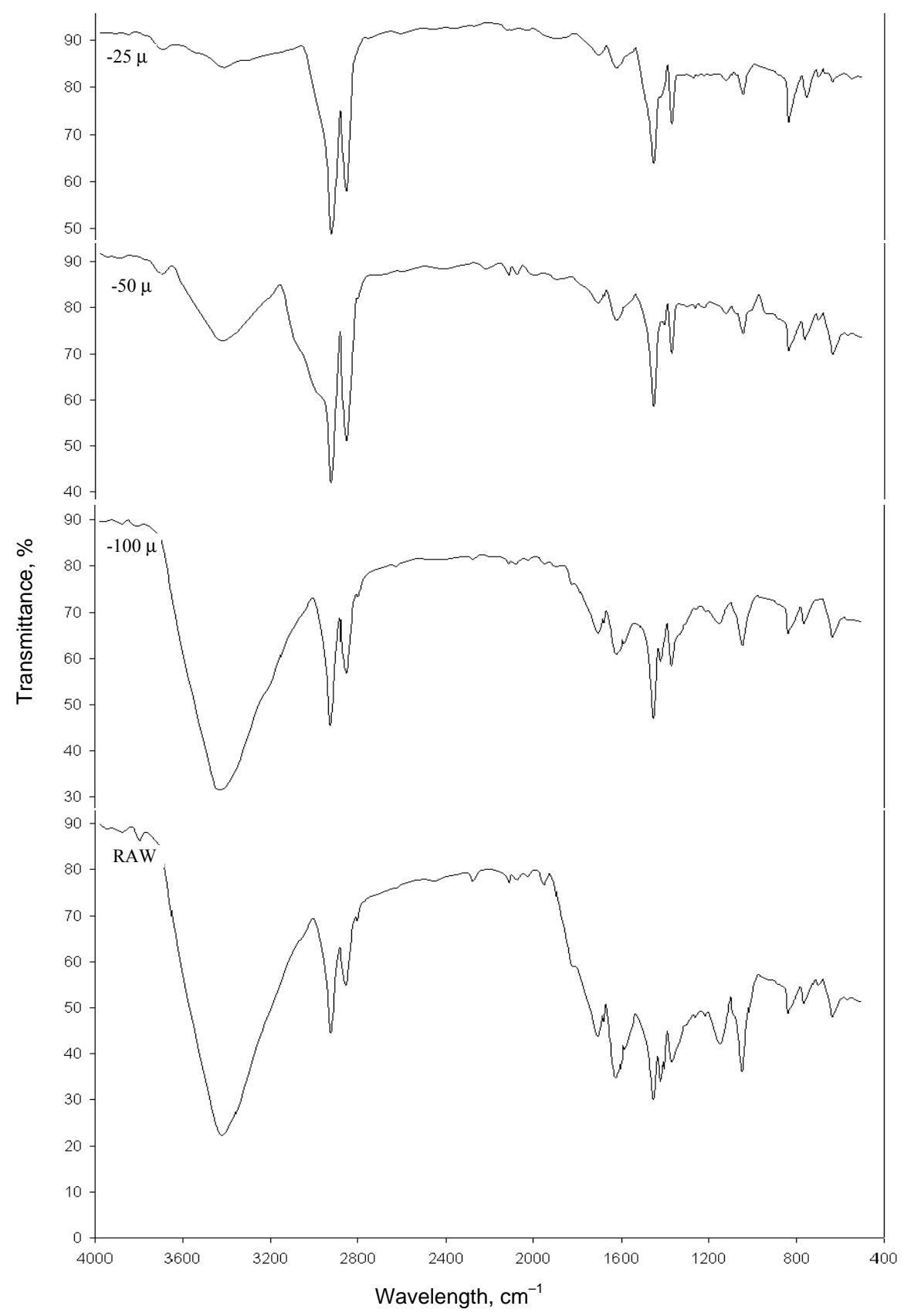

Fig. 2. FTIR spectrum of raw Himmetoğlu oil shale and comparative spectra with respect to grind size. 
$<25$ microns should be noted: at 25 microns the $\mathrm{OH}$ peak took a relatively slight form compared to other sizes and occurred in the form of a narrow band with a significant decrease in intensity. The sharp form of the $\mathrm{C}=\mathrm{O}$ peak at $1710 \mathrm{~cm}^{-1}$ became less pronounced and less steep with decreasing particle size. Also, the sharp $\mathrm{C}-\mathrm{OH}$ band at $1045 \mathrm{~cm}^{-1}$ apparently decreased in intensity and took the form of a quite less signified and a narrower peak at 25 microns. The same observation applies for the $\mathrm{C}=\mathrm{O}$ band at $1625 \mathrm{~cm}^{-1}$, where the peak became much smaller and took a less steep form with increasing fineness. The intensity of the aliphatic $\mathrm{C}-\mathrm{H}$ bands of $\mathrm{CH}_{3}$ and $\mathrm{CH}_{2}$ and aromatic $\mathrm{C}-\mathrm{C}$ and $\mathrm{C}=\mathrm{C}$ bands significantly increased with increasing fineness and reached a maximum at $<25$ microns (Fig. 2). The double $\mathrm{C}-\mathrm{H}$ bands at 2926 and $2850 \mathrm{~cm}^{-1}$ became quite sharper and intense with increasing fineness. Also the the $\mathrm{C}-\mathrm{H}$ peak at $2926 \mathrm{~cm}^{-1}$ took a broader form particularly at 50 and 25 microns (Fig. 2). The C-H peak at $1452 \mathrm{~cm}^{-1}$ occurred with a significantly increasing intensity and a broader form as the oil shale was ground finer. The broadness of the $\mathrm{C}-\mathrm{H}$ peak at $1372 \mathrm{~cm}^{-1}$ did not change, but the peak became much sharper and more intense at 25 microns compared to the raw sample. The successive $\mathrm{C}-\mathrm{H}$ and $\mathrm{C}-\mathrm{C}$ bands at 850 and $675 \mathrm{~cm}^{-1}$ increased in intensity with increasing fineness. The increase in the intensity and sharpness of the $\mathrm{C}-\mathrm{H}$ peak at $850 \mathrm{~cm}^{-1}$ at 25 microns should also be noted. These changes indicated that the humic character of the oil shale particle surfaces became less pronounced and the organic surface compounds increased with increasing fineness.

X-Ray photoelectron spectroscopy (XPS) is a useful tool in identifying the particle surfaces, particularly for the outermost layer and determining the concentrations of surface functional groups and/or elements [13]. The details of the XPS analysis of oil shale particles with respect to grind size are presented in Table 4. Only the amount of carbon increased with increasing fineness; as the grind size was decreased to $<25$ microns, the carbon amount on the particle surfaces increased from $30.60 \%$ to $64.90 \%$. The amount of inorganic matter $(\mathrm{O}, \mathrm{Ca}, \mathrm{Mg}, \mathrm{Si}, \mathrm{Fe})$ decreased significantly with decreasing grind size. Changes in the amounts of surface functional groups were also determined with increasing fineness (Table 4); the extent of $\mathrm{C}-\mathrm{H}, \mathrm{C}-\mathrm{C}$ and

Table 4. Surface characteristics of oil shale particles with respect to grind size

\begin{tabular}{|c|c|c|c|c|c|c|c|c|c|c|r|}
\hline \multirow{2}{*}{$\begin{array}{c}\text { Grind } \\
\text { size, } \\
\text { micron }\end{array}$} & \multicolumn{4}{|c|}{ Elemental composition, \% } & \multicolumn{4}{c|}{ Carbon functionalities, \% } \\
\cline { 2 - 12 } & $\mathrm{C}$ & $\mathrm{O}$ & $\mathrm{Ca}$ & $\mathrm{Mg}$ & $\mathrm{Si}$ & $\mathrm{Fe}$ & $\mathrm{C}-\mathrm{H}$ & $\mathrm{C}-\mathrm{C}$ & $\mathrm{C}=\mathrm{C}$ & $\mathrm{C}=\mathrm{O}$ & $\mathrm{C}-\mathrm{OH}$ \\
\hline$<200$ & 30.60 & 23.88 & 21.78 & 13.56 & 3.76 & 5.74 & 18.22 & 13.94 & 10.52 & 44.32 & 12.92 \\
$<150$ & 32.32 & 23.12 & 21.48 & 13.15 & 3.66 & 5.52 & 18.70 & 14.12 & 10.88 & 43.66 & 12.48 \\
$<100$ & 34.36 & 22.45 & 20.98 & 12.89 & 3.45 & 5.17 & 19.56 & 14.52 & 11.00 & 42.8 & 12.02 \\
$<75$ & 42.51 & 20.07 & 18.37 & 11.36 & 2.80 & 4.25 & 23.46 & 17.12 & 12.81 & 35.85 & 10.68 \\
$<50$ & 54.98 & 16.88 & 14.78 & 8.46 & 1.52 & 2.92 & 30.98 & 21.65 & 15.28 & 23.89 & 8.14 \\
$<35$ & 62.00 & 15.13 & 12.68 & 6.07 & 1.22 & 2.20 & 33.12 & 23.28 & 15.98 & 20.28 & 7.28 \\
$<25$ & 64.90 & 14.58 & 11.42 & 5.68 & 1.02 & 1.68 & 34.07 & 23.98 & 16.37 & 18.94 & 6.56 \\
\hline
\end{tabular}


$\mathrm{C}=\mathrm{C}$ bonds on the particle surface increased, but the $\mathrm{C}=\mathrm{O}$ and $\mathrm{C}-\mathrm{OH}$ functionals decreased. The $\mathrm{C}-\mathrm{H}, \mathrm{C}-\mathrm{C}$ and $\mathrm{C}=\mathrm{C}$ bonds belong to organic groups and $\mathrm{C}=\mathrm{O}$ and $\mathrm{C}-\mathrm{OH}$ bonds are due to polar carboxyl and carbonyl groups. Results of the XPS analysis together with the FTIR spectra reveal that with increasing fineness an organic-enriched layer or coating forms, and the influence of polar groups on oil shale particle surfaces decreases.

The highly hydrophilic character of Himmetoğlu oil shale means that it is highly wettable unlike most coals. Generally, in flotation cleaning of solid fossil fuels the native floatability or hydrophobicity of the fuel is utilized and the cleaned portion is obtained as a froth product. The "ash rich" portion, including the inorganic matter forms the reject and remains within the pulp. This process is called direct flotation. In case of immature and oxidized lignites or other solid fuels with polar surface characteristics the organic-rich particles exhibit a hydrophilic (water-avid) behavior rather than hydrophobicity [32-34]. In such cases direct flotation does not provide an effective separation and the process is reversed, i.e. reverse flotation is used. In reverse flotation, the surfaces of inorganic entities are rendered hydrophobic using certain surfactants and separated as a froth product, while the organic-rich portion remains within the pulp. This also applies for most oil shales owing to the presence of polar surface groups and a strong hydrophilic humic or fulvic character. In the flotation cleaning of Himmetoğlu oil shale the organic-rich particles did not exhibit hydrophobicity and were not naturally floatable [35]. Instead, the tailings portion, consisting mostly of carbonates was rendered hydrophobic using amine acetates and received as the froth product.

In addition to the specific hydrophilic feature of oil shales, the results of FTIR and XPS analysis showed the change of the surface characteristics with change in fineness. In solid fuels that are subject to changes in surface characteristics, finding out an optimum size becomes more critical. Figure 3 shows the separation performance of flotation cleaning of Himmetoğlu oil shale with respect to grind size of oil shale particles. The ash content of $20.48 \%$ at $<200$ microns decreased to $16.82 \%$ at $<100$ microns. Further reduction of the particle size increased the ash of the concentrate and the ash at $<25$ microns was $31.16 \%$. The change in the ash of the tailing with increasing fineness should also be noted; starting from $<200$ microns, ash of the tailing increased to $<100$ microns (Fig. 3). The highest ash of the tailing (69.26\%) attained at $<100$ microns was expected because at this size ash content of the concentrate was the lowest. Further increase in fineness caused a decrease in the ash of the tailing. The ash of the tailing (37.74\%) and the concentrate $(31.16 \%)$ approximated each other at $<25$ microns (Fig. 3). The weight of the concentrate and tailing with respect to grinding size is presented in Fig. 4. At $<200$ microns the weight of the concentrate was the highest (69.01\%), and the weight of tailings was at a minimum (30.99\%). Decreasing the grind size gradually decreased the weight of the concentrate. At $<25$ microns, the weight of the concentrate fell to $39.44 \%$. The weight of the tailings increased from $30.99 \%$ ( $<200$ microns) to $60.56 \%$ ( $<25$ microns) with increasing fineness. 


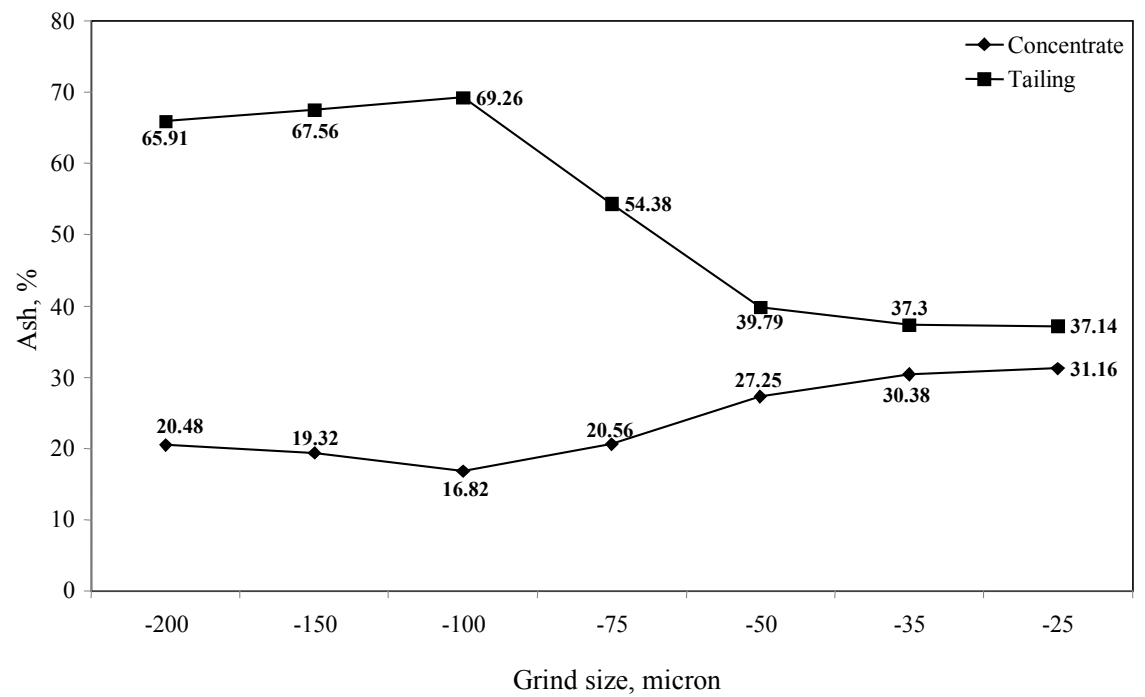

Fig. 3. Ash content of concentrate and tailing with respect to oil shale grind size.

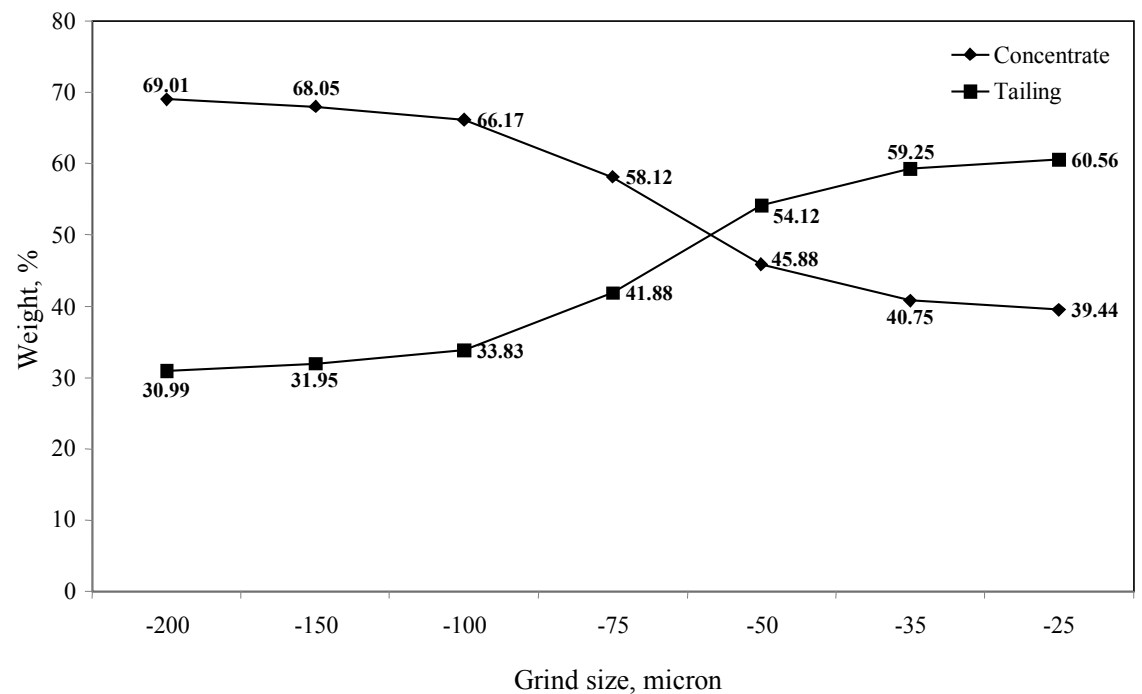

Fig. 4. Weight of concentrate and tailing with respect to oil shale grind size.

Variations in the ash and weight of the concentrate and tailing reveal the impact of the change of particle surface characteristics on the flotation performance. The highest extent of separation was achieved at $<100$ microns grind size, and further decrease in the particle size adversely affected ash separation. The change of the surface features, recorded by FTIR and XPS, particularly after $<100$ microns, should be noted (Fig. $2 \&$ Table 4). The increase in the ash of the concentrate from $<200$ microns to $<25$ microns 
indicates the gradual loss of selectivity with increasing fineness. The increase in the tailings weight with decreasing grind size (Fig. 4) points the increase in the amount of the froth product in reverse flotation. This increase occurred only with a change in the particle size all other flotation parameters being the same. This implies the change of the surface behavior of oil shale particles in flotation pulp with increasing fineness. The dramatic increase in the amount of tailings was attributed to increased hydrophobicity of the particles. The increase in hydrophobicity, however, adversely affected the selectivity of separation. The decrease in the ash content of the tailings with increasing fineness means that the significant amount of organic-rich particles reported to the froth incidentally due to the change of their surfaces from hydrophilic to hydrophobic state. The change of the surface behavior was further analyzed by electrokinetic measurements. The zeta potential of oil shale particles with increasing fineness is shown in Fig. 5. Oil shale particles had a high negative zeta potential of $-93 \mathrm{mV}$ at $<200$ micron size. It is well known that hydroxyl and carboxyl groups are acidic and negatively charged in water $[30,32,34,36]$. The relatively high negative charge of oil shale particles arises due to the polar-oxide functionals (Fig. 2). The high hydrophilicity of oil shale particles, the existence of the polar surface functionals and the high negative zeta potential correlate well.

The zeta potential of oil shale particles became less negative with increasing fineness (Fig. 5). Particularly, after $<100$ microns, significant changes were observed and the zeta potential was $-30 \mathrm{mV}$ at $<25$ microns. This change was attributed to the decrease of the polar surface functionals. It was seen that the extent of the polar groups on oil shale particle surfaces decreased significantly with increasing fineness. It was noted that the polar

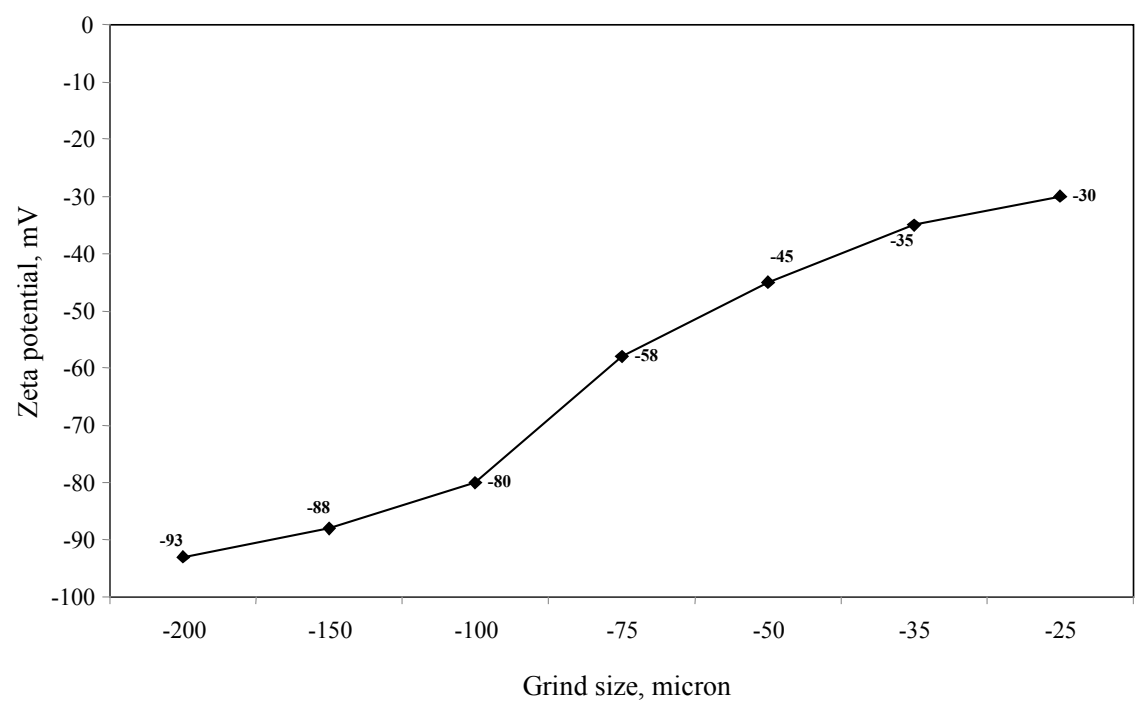

Fig. 5. Zeta potential of oil shale with respect to grind size. 
functionals imposed a high negative surface charge. Therefore, due to the decrease of these polar groups with increasing fineness, the zeta potential of oil shale particles shifted to less negative values. Zeta potential measurements were also very revealing about the change of the surface behavior and the flotation performance. The increase in hydrophobicity, related loss of selectivity and the shift of the zeta potential to less negative values imply that the particle surfaces were less controlled by the polar functional groups with increasing fineness.

The findings clarified that the change of the surface characteristics of the oil shale particles with increasing fineness relies on the release of organic matter and the formation or smearing of an organic-rich layer around oil shale particles. Bitumen constitutes some part of the organic matter in oil shale and comprises soluble and relatively lighter aliphatic and aromatic hydrocarbons $[7,37]$. Obtaining bitumen is an easier process compared to kerogen in oil shale, and bitumen would release during processes like comminution, flotation, etc. as shown by Sparks et al. [13] and Schramm et al. [14]. Himmetoğlu oil shale contained around 10\% bitumen. Factors such as the release of heat, increase of particle surface area, opening of micro and macro pores during grinding would provide a convenient environment for possible release of the bitumen and smearing of released bitumen around ground particles. In addition to the observations of Sparks et al. [13] and Schramm et al. [14], the release of bitumen and its association as an organic coating around particles with increasing fineness agrees well with the previous results about the release of bitumen by Larsen and Kidena [15] and the characteristics of the bitumen film by Diaz et al. [16]. Larsen and Kidena noted that the release of bitumen was not a thermal desorption process, but a physical phenomenon due to the liberation of bitumen from the source rock [15]. Diaz et al. revealed the tendency of free bitumen to aggregate and form a continuous film or an interfacial coating under convenient conditions [16].

In order to clarify the role of the bitumen in the change of the surface characteristics, the bitumen was extracted and the electrokinetic measurements and flotation tests with bitumen-free oil shale were repeated. The zeta potential of bitumen-free oil shale with respect to fineness is presented in Fig. 6 . The zeta potential of the bitumen-free oil shale particles fluctuated between $-86 \mathrm{mV}$ and $-77 \mathrm{mV}$, and the changes were not significant after bitumen extraction. A comparison of the electrokinetic results before and after bitumen extraction shows that bitumen release had a significant impact on the zeta potential of oil shale particles. This effect became more pronounced with increasing fineness. Bitumen-free oil shale particles had a high negative charge regardless of fineness. This showed that oil shale particle surfaces were controlled by polar-oxides if no bitumen released.

Figures 7 and 8 show the flotation results and the weight of the flotation products of bitumen-free oil shale with respect to grind size, respectively. With bitumen-free oil shale the ash of the concentrate decreased from $<200$ microns to $<75$ microns, then gradually increased with increasing 


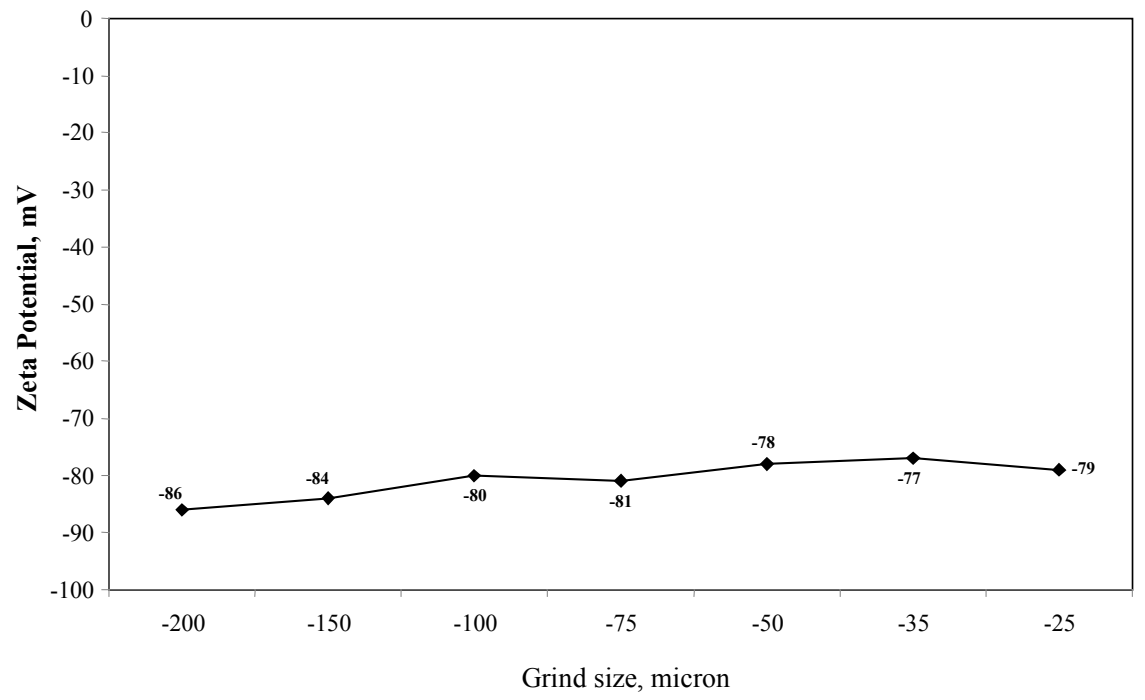

Fig. 6. Zeta potential of bitumen-free oil shale with respect to grind size.

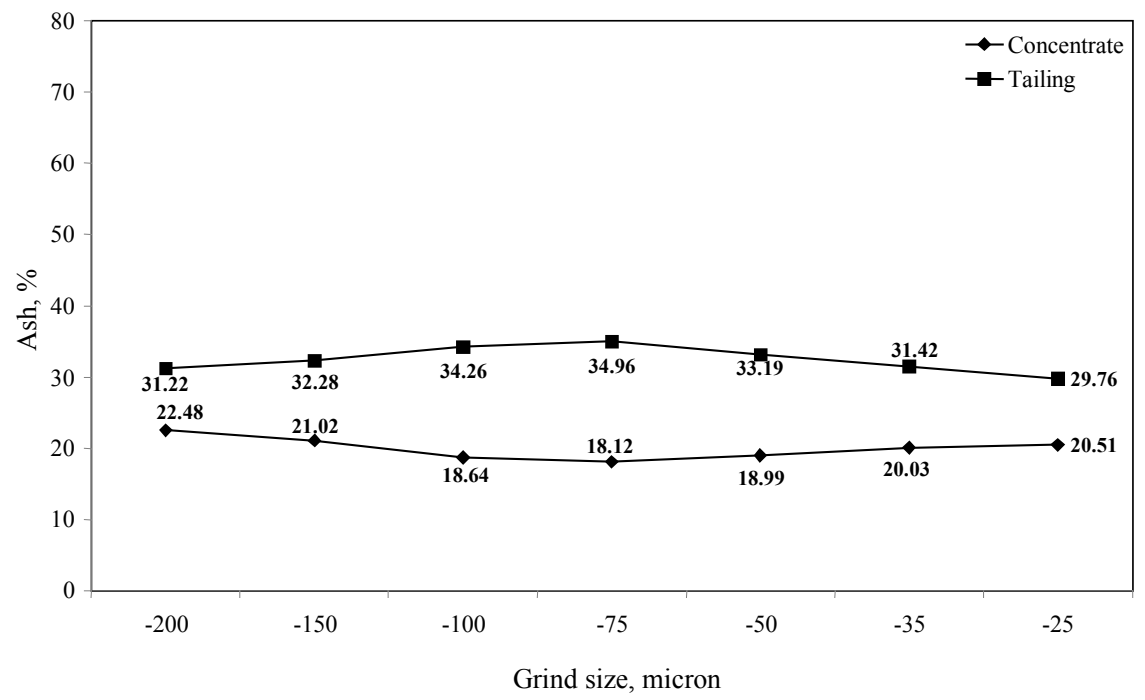

Fig. 7. Ash content of concentrate and tailing of bitumen-free oil shale with respect to grind size.

fineness (Fig. 7). The highest ash rejection was achieved at $<75$ micron size, and at this size the ash content of the cleaned oil shale decreases to $18.64 \%$. The lowest ash content attained with bitumen free oil shale is higher than lowest ash content attained with the raw oil shale. This increase is relative and due to the extraction of bitumen, i.e. the relative decrease of the organic matter after bitumen extraction. The increase in ash after $<75$ microns was 
limited compared to the increase with the raw oil shale (Figures $3 \& 7$ ). The limited changes were due to factors like the increase in slime formation, the fall in the effectiveness of flotation with decrease in particle size, etc, rather than a change in surface characteristics of oil shale particles. Also no sharp changes occurred in the ash of the tailing of bitumen-free oil shale (Fig. 7). With bitumen-free oil shale the change in the product weights remained limited with respect to fineness (Fig. 8). The weight of the concentrate fluctuated between $65.04 \%$ ( $<200$ microns) and $70.24 \%$ ( $<25$ microns). The lowest weight of the concentrate at $<75$ microns was an expected result since the ash of the concentrate was the lowest at this size. Same observations apply for the tailing, and the changes were limited compared to differences with the raw oil shale (Figures 4 and 8). These observations confirm that the surface characteristics of oil shale particles remain unchanged after bitumen extraction regardless of fineness.

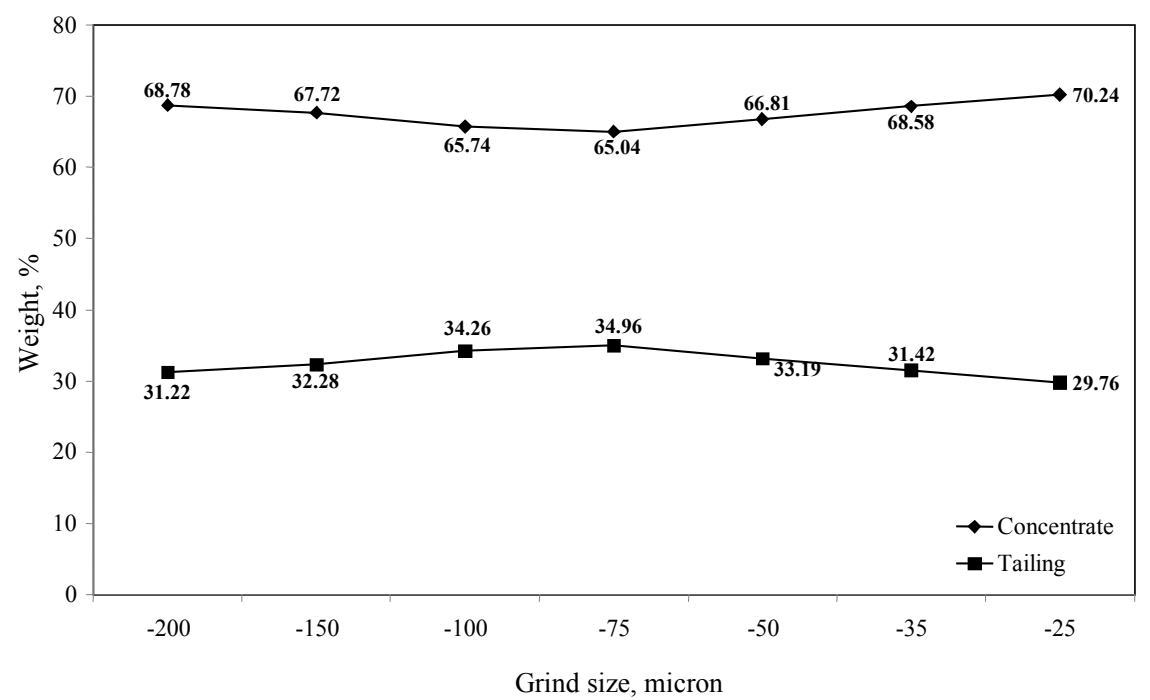

Fig. 8. Weight of concentrate and tailing of bitumen-free oil shale with respect to grind size.

\section{Conclusions}

Studies showed that bitumen has a vital impact on the surface chemistry of oil shale particles. The incidental release of bitumen occurs during particle size reduction at grind sizes finer than 100 microns. Bitumen release becomes more pronounced with increasing fineness. The release of bitumen causes an organic-rich surface coating. The loss of selectivity during flotation with increasing fineness shows that this "smearing effect" of bitumen is not selective, i.e. the released bitumen affects organic-rich oil shale 
particles as well as inorganic entities. The critical difference between hydrophilicity and hydrophobicity was lost gradually with the release of bitumen and this imparts the separation efficiency between organic and inorganic portions. In this respect it is of crucial importance to preserve the native surface characteristics of oil shale particles after size reduction. Determining the fineness degree at which the particle surface characteristics remain identical to the raw oil shale is critical for oil shale beneficiation, and over-grinding that would allow the release of bitumen should be avoided.

\section{REFERENCES}

1. EIA, Energy Information Administration. International Energy Annual 2001.Washington, DC, 2003.

2. Kök, M. V., Guner G., Bagci, S. Combustion kinetics of oil shales by reaction cell experiments // Oil Shale. 2008. Vol. 25, No. 1. P. 5-16.

3. Ballice, L., Reimert, R. Comparison of hydrocarbons formed at pyrolysis of Turkish Type I kerogen (Göynük) and Type II kerogen (Beypazari) // Oil Shale. 2005. Vol. 22, No. 3. P. 317-331.

4. Olivella, M. A., Heras de las, F.X.C. Nonisothermal thermogravimetry of Spanish fossil fuels // Oil Shale. 2006. Vol. 23, No. 4. P. 340-355.

5. Väli, E., Valgma, I., Reinsalu, E. Usage of Estonian oil shale // Oil Shale. 2008. Vol. 25, No. 2 Special. P. 101-114.

6. Hutton, A. C. Petrographic classification of oil shales // Int. J. Coal Geol. 1987. Vol. 8, No. 3. P. 203-231.

7. Yen, T. F., Chilingarian, G. V. (eds.). Oil Shale. - Amsterdam, 1976.

8. Datta, R. S., Salotti, C.A. Coarse beneficiation of Green River oil shale// Sixteenth Oil Shale Symposium Proceedings. Colorado: Colorado School of Mines Press, 1983. P. 413-425.

9. Krishnan, G. N., Farley, E. P., Murray, R. G. Beneficiation of U.S. oil shales by froth flotation// Sixteenth Oil Shale Symposium Proceedings. Colorado: Colorado School of Mines Press, 1983. P. 426-436

10. Wang, W. D., Zhou, C. Y. Retorting of pulverized oil shale in fluidized-bed pilot plant // Oil Shale. 2009. Vol. 26, No. 2. P. 108-113.

11. Al-Otoom, A. Y. An investigation into beneficiation of Jordanian El-Lajjun oil shale by froth floatation // Oil Shale. 2008. Vol. 25, No. 2. P. 247-253.

12. Altun, N. E., Hwang, J.-Y., Hicyilmaz, C. Enhancement of flotation performance of oil shale cleaning by ultrasonic treatment // Int. J. Miner. Process. 2009. Vol. 91 , No. 1. P. 1-13.

13. Sparks, B. D., Kotlyar, L. S., O'Carroll, J. B., Chung, K. H. Athabasca oil sands: effect of organic coated solids on bitumen recovery and quality // J. Petrol. Sci. Eng. 2003. Vol. 39, No. 3. P. 417-430.

14. Schramm, L. L., Stasiuk, E. N., Turner, D. The influence of interfacial tension in the recovery of bitumen by water-based conditioning and flotation of Athabasca oil sands // Fuel Process. Technol. 2003. Vol. 80, No. 2. P. 101-118.

15. Larsen, $J$. $W$., Kidena, $K$. The sudden release of oil and bitumen from Bakken shale on heating in water// Energy \& Fuels. 2002. Vol. 16, No. 4. P. 10041005 . 
16. Diaz, M. E., Montes, F. J., Galan, M. A. Langmuir films of bitumen and its fractions extraxted from oil shales (Puertollano, Spain) // Energy \& Fuels. 2007. Vol. 21, No. 6. P. 3455-3461.

17. Razvigorova, M., Budinova, T., Tsyntsarski, B., $\quad$ Petrova, B., Ekinci, E., Atakul, $H$. The composition of acids in bitumen and in products from saponification of kerogen: investigation of their role as connecting kerogen and mineral matrix // Int. J. Coal Geol. 2008. Vol. 76, No. 3. P. 243-249.

18. Sener, M., Senguler, I., Kok, M. V. Geological considerations for the economic evaluation of oil shale deposits in Turkey // Fuel. 1995. Vol. 74, No. 7. P. 9991003.

19. Kök, M. V., Guner, G., Bagci, S. Application of EOR techniques for oil shale fields (in-situ combustion approach) // Oil Shale. 2008. Vol. 25, No. 2. P. 217 225.

20. Altun, N. E., Hicyilmaz, C., Hwang, J.-Y, Bagci, A.S. Beneficiation of Himmetoğlu oil shale by flotation as a solid fuel substitute. Part 2. Process optimization by a statistical approach // Energy \& Fuels. 2006. Vol. 20, No. 1. P. 222-226.

21. Hazai, I., Alexander, G., Essiger, B., Szekely, T. Identification of aliphatic biological markers in brown coals // Fuel. 1988. Vol. 67, No. 7. P. 973-982.

22. Kruge, M. A., Hubert, J. F., Akes, R. J., Meriney, P. E. Biological markers in Lower Jurassic synrift lacustrine black shales, Hartford basin, Connecticut, U.S.A. // Org. Geochem. 1990. Vol. 15, No. 3. P. 281-289.

23. Mohammed, Z., Anabtawi, A., Uysal, B.Z. Extraction of El-Lajjun oil shale // Separ. Sci. Technol. 1995. Vol. 30, No. 17. P. 3363-3373.

24. Tissot, B. P., Welte, D. H. Petroleum Formation and Occurrence. - Berlin: Springer Verlag, 1984.

25. Ganz, H., Kalkreuth, W. Application of infrared spectroscopy to the classification of kerogen types and the evaluation of source rock and oil shale potentials // Fuel. 1987. Vol. 66, No. 5. P. 708-711.

26. Boukir, A., Guiliano, M., Asia, L., Hallaoui, A. El, Mille, G. A fraction to fraction study of photo-oxidation of BAL 150 crude oil asphaltenes // Analusis. 1998. Vol. 26, No. 9. P. 358-364.

27. Pompe, S., Schmeide, K., Bubner, M., Geipel, G., Heise, K. H., Bernhard, G., Nitsche, $H$. Investigation of humic acid complexation behavior with uranyl ions using modified synthetic and natural humic acids // Radiochim. Acta. 2000. Vol. 88. P. 553-558.

28. Stevenson, F. J. Humus chemistry: genesis, composition, reactions, 2nd Ed. New York, 1994.

29. Ouatmane, A., Dorazio, V., Hafidi, M., Revel, J. C., Senesi, N. Elemental and spectroscopic characterization of humic acids fractionated by gel permeation chromatography // Agronomie. 2000. Vol. 20, No. 5. P. 491-504.

30. Sarikaya, M., Özbayoğlu, G. Electrokinetics of oxidized coal // Fuel Process. Technol, 1990. Vol. 24. P. 459-466.

31. Holysz, L. Surface free energy and floatability of low-rank coal // Fuel. 1996. Vol. 75, No. 6. P. 737-742

32. Fuerstenau, D. W., Rosenbaum, J. M., Laskowski, J. Effect of surface functional groups on the flotation of coal // Colloids and Surfaces. 1983. Vol. 8, No. 2. P. 153-173.

33. Arnold, B. J., Aplan, F. F. The hydrophobicity of coal macerals // Fuel. 1989. Vol. 68, No. 5. P. 651-658. 
34. Bolat, E., Sağlam, S., Pişkin, S. The effect of oxidation on the flotation properties of a Turkish bituminous coal // Fuel Process. Technol. 1998. Vol. 55, No. 2. P. 101-105.

35. Altun, N. E., Hicyilmaz, C., Hwang, J.-Y., Bagci, A.S. Beneficiation of Himmetoğlu oil shale by flotation as a solid fuel substitute. Part 1. Materials characteristics and flotation behavior// Energy \& Fuels. 2006. Vol. 20, No. 1. P. 214-221.

36. Vamvuka, D., Agridiotis, $V$. The effect of chemical reagents on lignite flotation // Int. J. Miner. Process. 2001. Vol. 61, No. 3. P. 209-224.

37. Vitorovic, D, Sabana, M. Geolipids in Aleksinac oil shale // Geochemistry and Chemistry of Oil Shales / F. P. Miknis, J. F. McKay (eds.). Washington, D.C.: ACS Symposium Series 230, 1983. P. 36.

Presented by M. V. Kök

Received June 19, 2009 